\title{
ЗАСТОСУВАННЯ ОКИСНЮВАЛЬНОГО ПІРОЛІЗУ ДЛЯ ПЕРЕРОБКИ ОРГАНІЧНИХ ВІДХОДІВ
}

\author{
В.П. Клюс, канд. техн. наук; доцент, С.В. Клюс, канд. техн. наук; Н.О. Маслова \\ Інститут відновлюваної енергетики НАН України, \\ 02094, вул. Гната Хоткевича, 20А, м. Київ, Україна.
}

Виконано аналіз відомих методів переробки курячого посліду та осадів стічних вод. Запропоновано термічну переробку зазначених відходів методом окиснювального піролізу. Створено високотемпературну установку періодичної дї для проведення експериментальних досліджень. Вироблено гранули з посліду та осадів стічних вод.

В процесі окиснювального піролізу волога посліду перетворюється в пар, який взаємодіє з розпеченим вуглецем $i$ активує його. Після переробки маса посліду зменшується в 2-3 рази, а вміст поживних речовин $\left(\mathrm{P}_{2} \mathrm{O}_{5}, \mathrm{~K}_{2} \mathrm{O}\right)$ збільшується в порівнянні з вихідним продуктом. Отриманий продукт не містить патогенної мікрофлори, має пористу структуру і достатню механічну міиність, щзо важливо для його транспортування.

За результатами переробки посліду було отримано два продукти: карбонізований послід та горючий газ 3

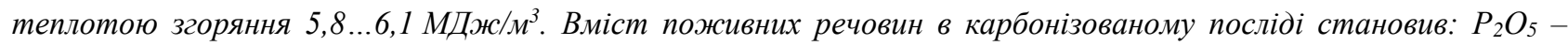
$(14,0 \ldots 18,8 \%) ; \mathrm{K}_{2} \mathrm{O}-(7,8 \ldots 11,1 \%)$. Активність по йоду - 22,3...24,2\%.

Для переробки були відібрані дві партії мулу: мул тривалого зберігання (понад 20 років) очисних споруд м. Києва та свіжий мул (3 роки) м. Львова.

В процесі переробки осаду стічних вод було встановлено, щчо при температурі $800-850{ }^{\circ} \mathrm{C}$ коксозольний залишок спікається, тому максимальну температуру було обмежено до $700{ }^{\circ} \mathrm{C}$. Вміст $\mathrm{P}_{2} \mathrm{O}_{5}$ в карбонізованому мулі становив $17,3 \ldots 23 \%$.

Проведеними експериментами підтверджена гіпотеза про можливість термічної переробки посліду і мулу методом окиснювального піролізу в нетрадииійні органічні добрива, які містять фосфор і калій.

Відповідно до Свропейського зеленого курсу (European Green Deal), планується скоротити застосування мінеральних добрив $i$ засобів захисту рослин на $20 \%$ найближчого десятиліття. Замінити традиційні мінеральні добрива можна органічними: карбонізованим послідом і карбонізованим мулом

Бібл. 11 , табл. 1, рис. 3.

Ключові слова: послід, каналізаційний мул, окиснювальний піроліз, нетрадиційні органічні добрива.

\section{APPLICATION OF OXIDIZING PYROLYSIS FOR PROCESSING OF ORGANIC WASTE}

V. Klius, candidate of technical science, docent, S. Klius, candidate of technical science, N. Maslova

Institute of Renewable Energy of the National Academy of Sciences of Ukraine, 02094, 20A Hnata Khotkevycha St., Kyiv, Ukraine.

The analysis of known methods of processing chicken manure and sewage sludge is performed. Thermal processing of these wastes by oxidative pyrolysis is proposed. The high-temperature installation of periodic action for carrying out experimental researches is created. Granules from manure and sewage sludge are produced. In the process of oxidative pyrolysis, the moisture of the manure is converted into steam, which interacts with the hot carbon and activates it. After processing, the mass of manure decreases by 2-3 times, and the content of nutrients $\left(\mathrm{P}_{2} \mathrm{O}_{5}, \mathrm{~K}_{2} \mathrm{O}\right)$ increases in comparison with the original product. The resulting product does not contain pathogenic microflora, has a porous structure and sufficient mechanical strength, which is important for its transportation.

As a result of manure processing, two products were obtained: carbonized manure and combustible gas with a heat of combustion of $5.8 \ldots 6.1 \mathrm{MJ} / \mathrm{m}^{3}$. The content of nutrients in the carbonized manure was: $\mathrm{P}_{2} \mathrm{O}_{5}-(14.0 \ldots 18.8 \%) ; \mathrm{K}_{2} \mathrm{O}$ $(7.8 \ldots 11.1 \%)$. Iodine activity - 22.3... $24.2 \%$.

Two batches of sludge were selected for processing: sludge of long-term storage (over 20 years) of sewage treatment plants in Kyiv and fresh sludge (3 years) of Lviv. 
In the process of sewage sludge treatment it was found that at a temperature of $800-850{ }^{\circ} \mathrm{C}$ the coke residue is sintered, so the maximum temperature was limited to $700{ }^{\circ} \mathrm{C}$. The content of $\mathrm{P}_{2} \mathrm{O}_{5}$ in the carbonized sludge was $17.3 \ldots 23 \%$.

The experiments confirmed the hypothesis of the possibility of thermal processing of manure and sludge by oxidative pyrolysis into unconventional organic fertilizers containing phosphorus and potassium.

According to the European Green Deal, it is planned to reduce the use of mineral fertilizers and plant protection products by $20 \%$ in the next decade. It is possible to replace traditional mineral fertilizers with organic: carbonized manure and carbonized sludge. Bibl. 11, table 1, fig. 3.

Keywords: manure, sewage sludge, oxidative pyrolysis, organic fertilizers.

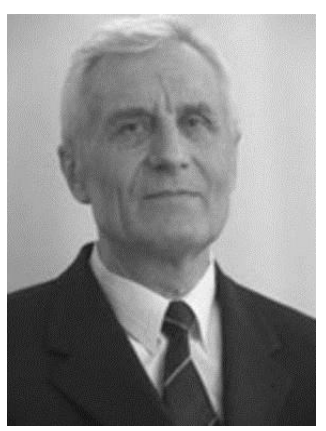

В.П. Клюс V. Klius

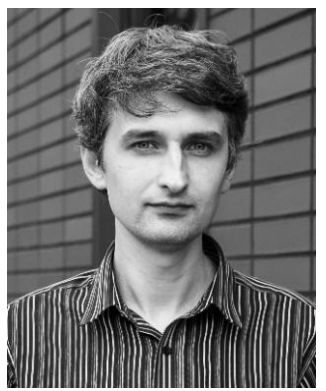

C.В. Клюс S. Klius

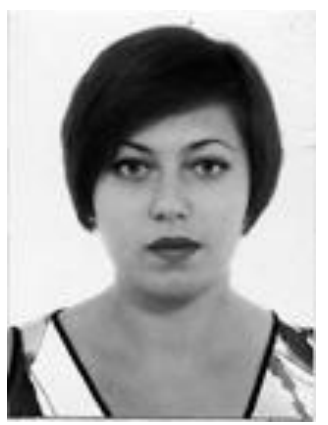

Н.О. Маслова N. Maslova
Відомості про автора: працює в Інституті відновлюваної енергетики НАН України, старший науковий співробітник. Кандидат технічних наук (1980 рік)

Освіта: Московський інститут хімічного машинобудування, спеціальність «Машини апарати хімічних виробництв»

Наукова сфера: біоенергетика, газифікація біомаси, переробка органічних відходів

Публікації: 102 наукових публікацій, зокрема 30 патентів

ORCID: 0000-0001-8536-3211

Контакти: тел./факс +38(044)206-28-09

e-mail: biomassa@ukr.net

Відомості про автора: працюе в Інституті відновлюваної енергетики НАН України, зав. відділу відновлюваних органічних енергоносіїв. Кандидат технічних наук (2016 рік) Освіта: Сумський державний університет, магістр обладнання хімічних виробництв та підприємств будівельних матеріалів

Наукова сфера: біоенергетика, газифікація біомаси, переробка органічних відходів Публікації: понад 30 наукових публікацій, зокрема 11 патентів

ORCID: 0000-0002-5804-4925

Контакти: тел./факс: +38 (044) 206-28-09

e-mail: biomassa@ukr.net

Відомості про автора: працюе в Інституті відновлюваної енергетики НАН України, молодший науковий співробітник

Освіта: Київський Національний Університет імені Тараса Шевченка, хімічний факультет

Наукова сфера: біоенергетика, газифікація біомаси, переробка органічних відходів Публікації: понад 20 наукових публікацій ORCID: 0000-0003-1465-1886

Контакти: тел./факс: +38 (044) 206-28-09 e-mail: biomassa@ukr.net
Author information: Institute of Renewable Energy of NAS of Ukraine, senior researcher. $\mathrm{PhD}$ since 1980

Education: Moscow Institute of Chemical Machine Building, specialty «Machine and Apparatus of Chemical Productions»

Research area: bioenergy, gasification of biomass, organic waste utilization

Publications: 102 scientific publications, including 30 patents

ORCID: 0000-0001-8536-3211

Contacts: tel./fax +38 (044) 206-28-09

e-mail: biomassa@ukr.net

Author information: Institute of Renewable Energy of NAS of Ukraine, head of bioenergy department. PhD since 2016

Education: Sumy State University, master of equipment of chemical productions and building materials enterprises

Research area: bioenergy, gasification of biomass, organic waste utilization

Publications: more than 30 scientific publications, including 11 patents

ORCID: 0000-0002-5804-4925

Contacts: tel./fax: +38 (044) 206-28-09

e-mail: biomassa@ukr.net

Author information: Institute of Renewable Energy of NAS of Ukraine, junior research fellow

Education: Taras Shevchenko National University of Kyiv, Faculty of Chemistry

Research area: bioenergy, gasification of biomass, organic waste utilization

Publications: more than 20 scientific publications

ORCID: 0000-0003-1465-1886

Contacts: tel./fax: +38 (044) 206-28-09

e-mail: biomassa@ukr.net
Вступ. Наразі можна виділити два основні види органічних відходів, нарощування обсягів яких призводить до погіршення екологічної ситуації, а також спричиняє соціальне напруження серед населення, що проживає в районах їх зберігання. Це осад стічних вод (каналізаційний мул) і курячий послід.
Промислове птахівництво - одна 3 галузей сільського господарства, яка розвиваються найдинамічніше. Очевидно, що поряд iз забезпеченням населення продуктами птахівництва в галузі виникла гостра проблема 3 утилізацією великих і постійно збільшуваних обсягів курячого посліду. Основним видом 
курячого посліду є підстилковий послід, який накопичується на підстилці при підлоговому утриманні курей м'ясних порід. Як підстилку використовують тирсу, лушпиння соняшника, січку соломи, які засипають на підлогу, а потім у пташник запускають інкубаційних курчат. Час відгодівлі курчат - два місяці. Після чого курей відправляють на забій, а 3 пташника прибирають підстилковий послід, що має вологість приблизно 30-40 \%. Вологість безпідстилкового посліду при клітковому утриманні курей-несучок становить 75-80 \%, а при гідрозмиві може досягати $85 \%$.

Пташиний послід належить до відходів IV класу небезпеки. Згідно зі статтею 246 Податкового Кодексу України, для відходів цього класу застосовується коефіцієнт, який залежить від місця розміщення відходів. Ставки податку збільшуються втричі за умови розміщення відходів:

1) на звалищах, які не забезпечують повне виключення забруднення атмосферного повітря або водного об'єкта;

2) в межах населеного пункту або на відстані менше ніж 3 км від таких меж.

Птахофабрика звільняється від оподаткування, якщо вона утилізує пташиний послід, або реалізує його споживачам.

Найпростішим i найпоширенішим способом переробки посліду $є$ компостування. Однак під час компостування близько $30 \%$ поживних речовин втрачається у вигляді газів, завдаючи екологічної шкоди. При транспортуванні компосту на відстань понад 10 км витрати на внесення в грунт не окупаються збільшенням врожайності [1].

Інша технологія переробки посліду мікробіологічна. Послід переробляється в метантенках з отриманням біогазу та дефекату. I якщо проблем із застосуванням біогазу немає, то великі обсяги рідкого дефекату економічно не вигідно транспортувати, як і компост.

Основний метод поводження 3 осадом стічних вод - складування на мулових полях. Переповнення мулових полів призводить до забруднення грунту, атмосфери й розповсюдження патогенної мікрофлори. Відомо, що осад тривалого зберігання за структурою й теплотою згоряння відповідає торфу i може застосовуватися як тверде паливо. Так, наприклад, на очисних спорудах м. Брно (Чехія), у Гросвільферсдорфі (Австрія) мул спалюють в котлоагрегатах. Технологія підготовки й спалювання мулу досить складна, а вартість спалювання 1 т мулу на установці киплячого шару в Австрії близько 40 євро [2], на очисних спорудах м. Брно становить близько 1000 крон [3].

Отже, наявні технології переробки курячого посліду й осадів стічних вод складні й потребують значних капітальних вкладень. $€$ потреба в пошуку нових, екологічно безпечних технічно доступних, технологій. Серед таких технологій, на нашу думку, може розглядатися порівняно нова технологія окиснювального піролізу (часткової газифікації) твердого палива.

Окиснювальний піроліз реалізується у вертикальних реакторах щільного шару палива 3 розміром частинок $5 . .40 \mathrm{Mm}$ i обмеженою подачею повітря в кількості 5-7 \% від теоретично необхідного для повного згоряння [4].

Теоретичні й практичні основи окиснювального піролізу (часткової газифікації) бурого вугілля досить широко представлені, наприклад, в роботах $[5,6]$. Основні переваги технології: автотермічність процесу, можливість переробки палива вологістю до 45-50\%, отримання двох продуктів - карбонізованого залишку й горючого газу.

Виходячи 3 власного досвіду переробки вологої деревної біомаси методом окиснювального піролізу [7, 8], було висунуто гіпотезу про можливість термічної переробки багатотоннажних органічних відходів у нетрадиційні добрива нового виду.

Експериментальні дослідження. Для переробки посліду й мулу були виготовлені гранули діаметром $6 \ldots 8$ мм. Окиснювальний піроліз гранул проводили на високотемпературній експериментальній установці, схема якої представлена на рис. 1. Матеріал реактора - титановий сплав ВТ-16, об'єм - 4 дм $^{3}$. 


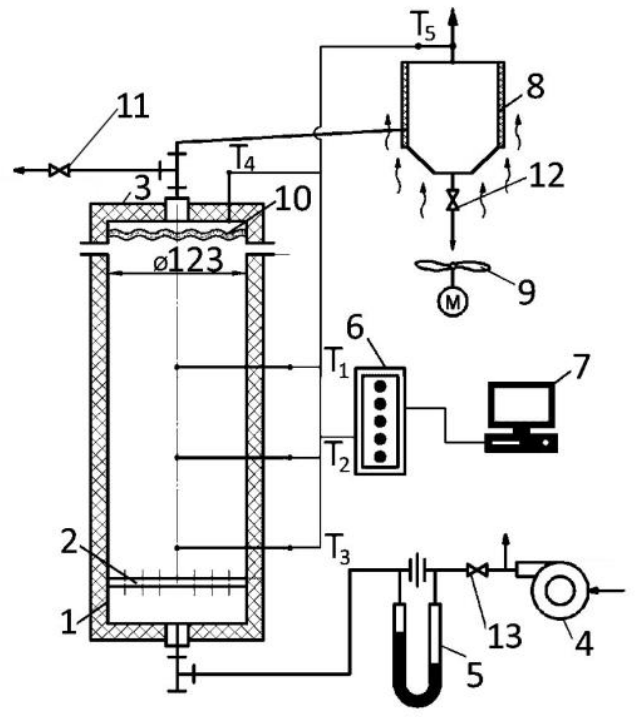

Рис. 1. Схема експериментальної установки: 1 - реактор; 2 - колосникова решітка; 3 - кришка реактора;

4 - повітродувка; 5 - дифманометр; 6 - вимірювач температури; 7 - комп'ютер; 8 - холодильник-конденсатор; 9 - вентилятор; 10 - фільтр високотемпературний; 11 - кран для відбору газу; 12 - кран дренажний; 13 - засувка повітряна; (T1-T5) - термопари XА

Fig. 1. Scheme of experimental installation: 1 - reactor; 2 - grating; 3 - reactor lid; 4 - blower; 5 - differential pressure gauge; 6 - temperature meter; 7 - computer; 8 - refrigerator-condenser; 9 - fan; 10 - high-temperature filter; 11 - the valve for gas sampling; 12 - the drain valve; 13 - air latch; (T1-T5) - thermocouples

Робота установки. Гранули завантажують у реактор, запалювання відбувається зверху, а регульоване повітря подається знизу. В результаті первинного нагріву 3 гранул виділяються леткі речовини, які, частково згораючи, утворюють фронт горіння по всьому перетину реактора. Кисень повітря повністю витрачається у фронті горіння. Фронт горіння летких речовин рухається зверху вниз назустріч повітрю, а за ним залишається карбонізований продукт. 3 реактора виводиться горючий газ, який спалюється в котлоагрегатах або на свічці. Після досягнення фронтом горіння колосникової решітки процес карбонізації завершується. Реактор охолоджується, потім 3 нього вивантажують карбонізований продукт. В процесі експериментів контролювали такі параметри: маса завантажених гранул, вологість і зольність гранул, витрата повітря дуття, покази термопар.

Переробка посліду. Досліджували процес піролізу підстилкового посліду курей домашнього утримання i 3 птахофабрики. Результати окиснювального піролізу посліду представлені в табл. 1.

\section{Таблиця 1. Результати піролізу}

Table 1. The results of pyrolysis

\begin{tabular}{|c|c|c|c|}
\hline № ח/П & Показники & Послід домашній & $\begin{array}{c}\text { Послід } \\
\text { птахофабрики }\end{array}$ \\
\hline 1. & Вологість гранул, \% & 40,2 & 29,1 \\
\hline 2. & Зольність гранул, \% & 36,8 & 28,9 \\
\hline 3. & Температура в реакторі, ${ }^{0} \mathrm{C}$ & $650-820$ & $600-780$ \\
\hline 4. & Швидкість руху фронту горіння летких речовин, см/год & 28,2 & 31,0 \\
\hline 5. & Вихід карбонізованого посліду, \% & 47,2 & 30,6 \\
\hline 6. & Вміст $\mathrm{P}_{2} \mathrm{O}_{5}$ в карбонізованому посліді, \% & 14,0 & 18,8 \\
\hline 7. & Вміст $\mathrm{K}_{2} \mathrm{O}$ в карбонізованому посліді, \% & 11,1 & 7,8 \\
\hline 8. & Активність за йодом карбонізованого посліду, \% & 24,2 & 22,3 \\
\hline 9. & Нижча теплота згорання горючого газу, МДж/м³ & 6,1 & 5,8 \\
\hline 10. & Питома продуктивність за вологими гранулами, кг/(м².год) & 82,5 & 95,3 \\
\hline
\end{tabular}


У процесі окиснювального піролізу волога посліду перетворюється на пар, який взаємодіє 3 розпеченим вуглецем й активує його. Після переробки маса посліду зменшується в 2-3 рази, а вміст поживних речовин $\left(\mathrm{P}_{2} \mathrm{O}_{5}, \mathrm{~K}_{2} \mathrm{O}\right)$ збільшується в порівнянні з вихідним продуктом. Отриманий продукт не містить патогенної мікрофлори, має пористу структуру і достатню механічну міцність, що важливо для його транспортування.

Серед недоліків установки слід зазначити невисоку продуктивність і періодичність процесу переробки. Для підвищення продуктивності нами була розроблена установка безперервної дії [9].

Установка складається 3 реактора об'ємом 10 дм³ $^{3}$ виготовленого 3 кварцової труби з метою візуалізації процесу, шлюзової засувки, холодильника-конденсатора i димососа 3 напругою живлення 12 В. Установка під розрідженням, розпал палива знизу реактора, напрямок руху фронту горіння летких речовин знизу вгору, назустріч потоку повітря. На рис. 2 представлено фото установки після завершення переробки гранул з посліду.

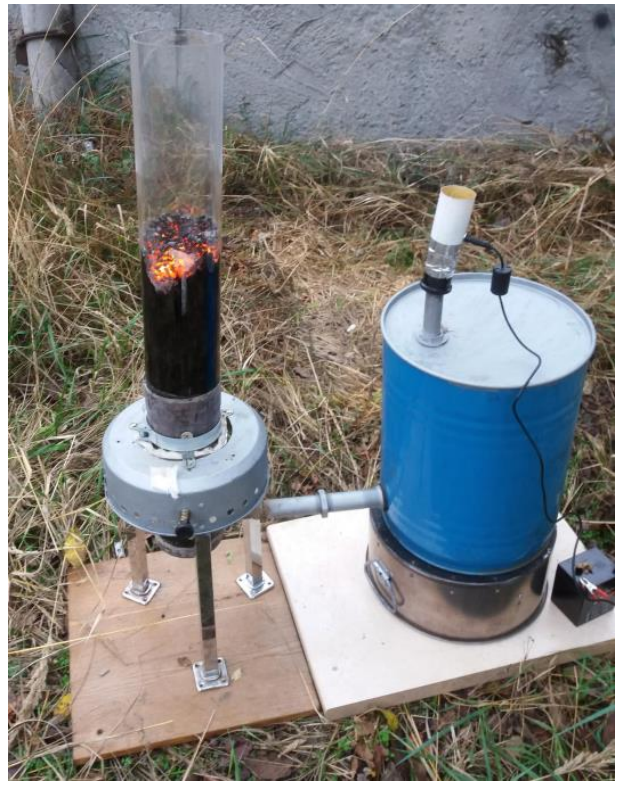

Рис. 2. Фото установки

Fig. 2. Photo of installation

На установці проводилася термічна 120 кг/( $\mathrm{M}^{2} \cdot$ год), а також зменшення маси посліду переробка гранульованого посліду торгової більш ніж у 2 рази. Температура процесу марки «Курник», виробленого за ТУУ $24.1-$ перебувала в межах $700-800{ }^{\circ} \mathrm{C}$. 20487748-003: 2011.

Гранули «Курник» були розфасовані в герметичну пластикову упаковку, 3 огляду на стійкий специфічний запах. За результатами вхідного аналізу вологість гранул склала $29,3 \%$, зольність - 39,1\%. Спочатку в нижню частину реактора завантажували розпечене деревне вугілля. Потім в реактор завантажували сирі гранули, а карбонізовані виводили через шлюзову засувку в міру їх охолодження. В результаті проведення експериментів було встановлено підвищення продуктивності до
У 2018 році в рамках дрібноділяночних експериментів порошкоподібний карбонізований послід, вироблений методом сухого піролізу, вносився в грунт під пшеницю і під ячмінь. Застосування нового нетрадиційного добрива привело до збільшення врожайності пшениці на $41 \%$ і ячменю - на 46 \%. При спільному внесенні мінеральних добрив і карбонізованого посліду врожайність ячменю підвищилася на $76 \%$ за рахунок синергетичного ефекту. Відзначено, що внесення карбонізованого посліду підвищило якість зерна і його хлібопекарські властивості. 
Після іммобілізації карбонізованого посліду йодом його вміст у зерні збільшився на $30 \%$, що має важливе значення для здоров'я населення. Також внесення карбонізованого посліду сприяло збільшенню грунтового дихання [10].

Отже, переробка посліду термічними методами приводить до отримання нового нетрадиційного добрива. 3 огляду на те, що окиснювальний піроліз протікає в автотермічному режимі і в результаті піролізу додатково до горючого газу отримуємо карбонізований послід, варто очікувати, що собівартість переробки посліду окиснювальним піролізом буде нижча, ніж при сухому піролізі. Якість карбонізованого посліду, отриманого методом окиснювального піролізу вища, ніж при сухому піролізі, в результаті його активації водяною парою при температурі понад $600{ }^{\circ} \mathrm{C}$.

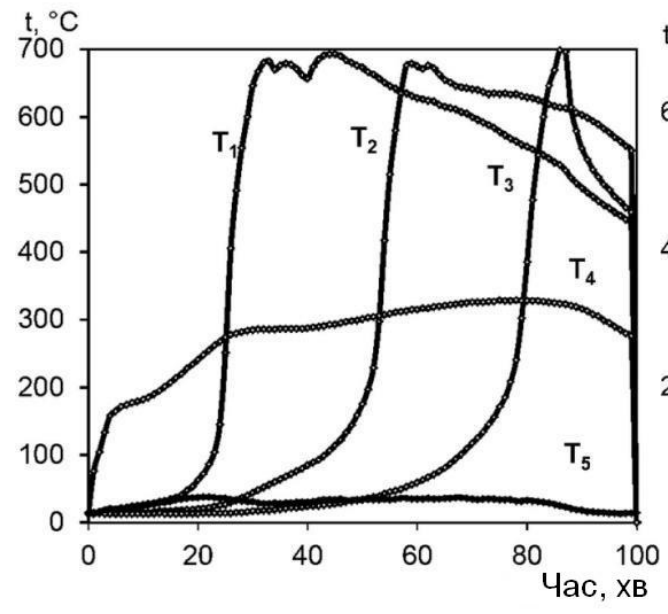

$a$
Переробка осадів стічних вод (каналізаційного мулу). Для переробки були відібрані дві партії мулу: мул тривалого зберігання (понад 20 років) очисних споруд м. Києва та свіжий мул (3 роки) 3 м. Львова. 3 мулу були виготовлені гранули діаметром 6 мм і довжиною $10 \ldots 12$ мм. 3 огляду на високу зольність мулу, 36,8...42,4 \%, гранули сушилися під навісом до вологості 14-16\%. Окиснювальний піроліз мулу проводили в тій самій послідовності, що і посліду. Було встановлено, що при температурі $800-850{ }^{\circ} \mathrm{C}$ коксозольний залишок спікається по всьому перетину реактора і тим самим перешкоджає проходженню повітря через шар гранул. Тому наступні експерименти проводили при температурі не більше $700{ }^{\circ} \mathrm{C}$. На рис. 3 наведено динаміку зміни температури в реакторі.

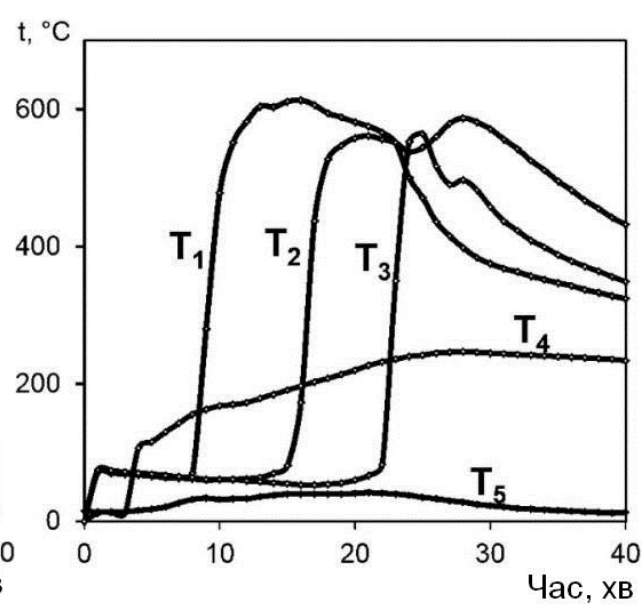

6

Рис. 3. Динаміка зміни температури в реакторі при окиснювальному піролізі мулу: $a$ - мул 3 м. Києва; $\sigma$ - мул 3 м. Львова

Fig. 3. Dynamics of temperature change in the reactor during oxidative pyrolysis of sludge

Вихід карбонізованого мулу склав $53 \%$ (м. Київ) та 63 \% (м. Львів) від сухої маси гранул. Нижча теплота згоряння горючого газу склала

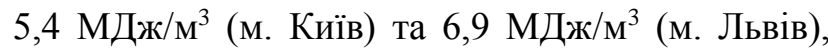
що приблизно відповідає горючості газу, отриманого 3 посліду. Вміст $\mathrm{P}_{2} \mathrm{O}_{5} \quad$ у карбонізованому мулі склав 17,3-23,0\%, що більше, ніж в карбонізованому посліді. У той же час $\mathrm{K}_{2} \mathrm{O}$ був виявлений у невеликій кількості, $2,2 \%$, тільки в карбонізованому мулі зі Львова.

Висновки. Проведені експерименти підтверджують гіпотезу про можливість термічної переробки посліду й мулу методом окиснювального піролізу на нетрадиційні органічні добрива, які містять фосфор і калій.

Відповідно до Європейського зеленого курсу, прийнятого в грудні 2019 року (European Green Deal), планується скоротити застосування мінеральних добрив і засобів захисту рослин на $20 \%$ найближчого десятиліття [11]. Замінити традиційні мінеральні добрива можна органічними: карбонізованим послідом і карбонізованим мулом. Відомі установки окиснювального піролізу періодичної дії та 
установки безперервної дії, які розробляються, не містять рухомих елементів, що піддаються впливу високої температури $600-800 \quad{ }^{\circ} \mathrm{C}$ i працюють в автотермічному режимі без застосування додаткового палива. Карбонізовані добрива, отримані в цих установках, активуються водяною парою, мають розвинену пористу вуглецеву структуру й достатню механічну міцність.

1. Мельник В.О. Екологічні проблеми сучасного птахівництва. Міжвідомчий науковий тематичний збірник «Птахівництво». 2009. Вип. 63. С. 1-15.

2. Карп I.М., П'яних К.Є., Нікітін С.С. Проблема утилізації та знешкодження мулових осадів міських стічних вод і шляхи іiі вирішення (Огляд). Энерготехнологии и ресурсосбережение. 2017. № 2. С. 35-48.

3. Biela R., Shevehikova I. Možnosti zpracování vodárenských kalů, 2021. URL: https://voda.tzb-info.cz/12241moznosti-zpracovani-vodarenskych-kalu (дата звернення: $12.02 .2021)$

4. Булкатов А.Н., Мовсум-Заде Э.М., Мясоедова B.B. Газификация углей, горючих сланцев и других видов органического топлива. Химическое и нефтегазовое машиностроение. 2009. № 10. С. 15-18.

5. Степанов С.Г., Исламов С.Р., Морозов А.Б. Технология совмещенного производства полукокса и горючего газа из угля. Уголь. 2002. № 6. С. 27-29.

6. Исламов С.P. Энерготехнологическая

переработка бурого угля в топливном котельном агрегате. Промышленная энергетика. 2015. № 2. С. 25-28.

7. Клюс С.В. Експериментальні дослідження процесів енерготехнологічного перетворення біомаси в реакторах щільного шару палива. Відновлювана енергетика. 2015. № 3. C. 85-92.

8. Клюс С.В., Жовмір М.М., Маслюкова З.В., Демчина В.П. Визначення основних показників та ефективності часткової газифікації біомаси в газогенераторі щільного шару 3 оберненим дуттям. Відновлювана енергетика. 2016. № 2. С. 79-87.

9. Патент України № 143271 від 27.07.2020 p Реактор піролізний. Клюс В.П., Клюс С.В.

10. Rudakova M., Galitskaya P., Selivanovskaya $S$ Quality of Biochar and Fuels Obtained in the Process of Slow Pyrolysis of Chicken Manure. Proceedings of the 27th European Biomass Conference and Exhibition. 27-30 May 2019 Pp. 1249-1254.

https://doi.org/10.5071/27thEUBCE2019-3BV.7.31

11. Communication from the Commission to the European Parliament, the European Council, the European Economic and Social Committee and the Committee of the Regions. 2019. URL:

https://ec.europa.eu/info/sites/default/files/european-green-dealcommunication_en.pdf (дата звернення: 12.02.2021)

\section{REFERENCES}

1. Melnik V.O. Ekolohichni problemy suchasnoho ptakhivnytstva. [Ecological problems of modern poultry farming]. Interdepartmental scientific thematic collection "Poultry". 2009. No. 63. Pp. 3-15. [in Ukrainian].

2. Karp, I., Pyanykh, K. and Nikitin, Y. The Problem of Disposal and Destruction of Sewage Sludge and its Solutions (Review). Energy Technologies \& Resource. 2017. No. 2. Pp. 35-48. doi: https://doi.org/10.33070/etars.2.2017.05

[in Ukrainian].

3. Biela R., Shevehikova I. Možnosti zpracování vodárenských kalů. [Possibilities of water treatment sludge processing]. URL: https://voda.tzb-info.cz/12241-moznostizpracovani-vodarenskych-kalu. (Applying date: 12.02.2021) [in Czech].

4. Bulkatov, A.N., Movsum-zade E.M., Myasoedova V.V. Gazifikatsiya ugley, goryuchikh slantsev i drugikh vidov organicheskogo topliva. [Gasification of coals, combustible shales and other types of organic fuel]. Chem Petrol Eng. 2009. No. 10. Pp. 15-18. https://doi.org/10.1007/s10556010-9223-y. [in Russian].

5. Stepanov S.G., Islamov S.R. et al. Tekhnologiya sovmeshchennogo proizvodstva polukoksa i goryuchegogaza iz uglya. [Technology of combined production of semi-coke and combustible gas from coal]. Ugol' [Coal]. 2002. No. 6.

Pp. 27-29. [in Russian]

6. Islamov S. R. Energotekhnologicheskaya

pererabotka burogo uglya $\mathrm{v}$ toplivnom kotel'nom aggregate. [Energotechnological processing of brown coal in a fuel boiler unit..] Promyshlennaya energetika. [Industrial power engineering]. 2015. No. 2. Pp. 25-28. [in Russian].

7. Klius S.V. Eksperymentalni doslidzhennia procesiv energotehnologichnogo peretvorennia biomasy $\mathrm{v}$ reaktorah shchil'nogo sharu palyva. [Experimental studies of energytechnological biomass conversion processes in dense fuel layer reactors]. Vidnovluvana energetika. 2015. No. 3. Pp. 85-92.

[in Ukrainian]

8. Klius S. V. Zhovmir M. M., Masliukova Z. V., Demchyna V.P. Vyznachennia osnovnyh pokaznykiv ta efektyvnosti chastkovoi gazyfikacii biomasy $\mathrm{v}$ gazogeneratori shchil'nogo sharu $\mathrm{z}$ obernenym duttiam. [Evaluation of main parameters and efficiency of partial biomass gasification in fixed bed gasifier with inverse blowing]. Vidnovluvana energetika. 2016. No. 2. Pp. 79-87. [in Ukrainian].

9. Patent of Ukraine № 143271 dated July 27, 2020. Pyrolysis reactor. Klyus V.P., Klyus S.V. [in Ukrainian]

10. Rudakova $M$, Galitskaya $P$, Selivanovskaya $S$. Quality of Biochar and Fuels Obtained in the Process of Slow Pyrolysis of Chicken Manure. Proceedings of the 27th European Biomass Conference and Exhibition. 27-30 May 2019. Pp. 1249-1254. https://doi.org/10.5071/27thEUBCE20193BV.7.31 [in English].

11. Communication from the Commission to the European Parliament, the European Council, the European Economic and Social Committee and the Committee of the Regions. 2019. URL:

https://ec.europa.eu/info/sites/default/files/european-green-dealcommunication_en.pdf (Applying date: 12.02.2021). [in English] 